\title{
The Current Situations and the Strategies of General English Education in Chinese University
}

\author{
Ying Gao ${ }^{1, *, \dagger}$, Han $\mathrm{Hu}^{2, \dagger}$, Yudi Zhou ${ }^{3, \dagger}$ \\ ${ }^{1}$ Foreign Language college, NanJing Agricultural University; NanJing, 210095, JiangSu Province, China \\ ${ }^{2}$ School of Physical Education, Hubei University, Wuhan, 430062 Hubei Province, China \\ ${ }^{3}$ Yangtze University, Jingzhou, 434002, Hubei Province, China \\ *Corresponding author.Email:20143246@stu.nun.edu.cn \\ ${ }^{\top}$ Those authors contributed equally.
}

\begin{abstract}
General education is a type of educational model based on Aristotle's free education thought. The goal of it is to provide interdisciplinary knowledge for students, supple professional education further and make it a complete person in current pluralistic society. As an indispensable part of general education, the goal of university English education is to improve students' comprehensive English application ability, cultivate comprehensive cultural literacy and international communication ability, and make students cross-cultural exchange talents with international vision, familiar with international rules and able to participate in international affairs. This paper reviews the educational ideas and objectives of general education. Combined with the current situation of English education in Chinese colleges and universities, this paper combs the influence of general education on college English teaching, and puts forward the guiding strategies to improve college English education from three aspects: (1) Competency-based instructing system; (2) Combining language and cultural learning; (3) English in major studying.
\end{abstract}

Keywords: General education, University English education, English course revolution

\section{INTRODUCTION}

General education, concerning with the integration of disciplines, as well as the improvement of the ability to analyze, synthesize and extract information from related things, and it can be considered that it is a further supplement of specialized education. It is widely adopted in Chinese universities, especially in English course. However, it was taught more as a tool of communication and a means of obtaining information. Apart from that, English is also a tool as an international language to transmit culture, and it is compatible with instrumentality and humanity. This paper focuses on the development of general education and the contemporary problems existed in general English education, including the single tool of general education, the lack of humanity, the lack of communicative ability training. The strategies are also offered in this paper, which are aimed to cultivate professional talents with international visions and intercultural communication.

\section{DEVELOPMENTS AND CURRENT SITUATIONS OF GENERAL ENGLISH EDUCTION}

At the end of the 20th century, experts in Chinese pedagogy looked back at the history and development of higher education. They realized that university education placed too much emphasis on the study of professional knowledge and skills and ignored that the essence of education is to train complete people. With the development of the idea of general education in the field of education, university English as an important part of higher education has also been greatly affected. In 2004, the Higher Education Department of the Ministry of Education issued the "University English Course Teaching Requirements (Trial)", which clearly pointed out: "College English Teaching goal is to train students' comprehensive ability in English, while enhancing its autonomous learning ability, improve the cultural quality of its integrated in order to meet the needs of China's economic development and international exchanges" [1]. We can clearly conclude that the purpose of college English teaching is no longer to use English as the 
learning content, but to use English as the carrier of knowledge, which means that English is used as a tool to learn all aspects of knowledge and train students to become talents of comprehensive quality.

In the nearly two decades from 2003 to 2021, Chinese university English general education research has gone through three stages, starting from exploration, developing rapidly, and developing steadily. The research hot topic of college English general education is whether the development direction of college English teaching is general English or academic English; generalized teaching and curriculum reform ideas of college English; the development of teaching mode, etc.

\subsection{The Relationship Between University English and General Education}

Regarding the relationship between college English and general education, scholars mainly have three different views: The first view is that college English is a part of general education. Yin and Yan believes that college English general education is an important part of general education, which is able to expand the scope of general education in schools [2]. The second view is that college English courses cannot independently undertake the important task of general education. Chen and $\mathrm{Gu}$ believe that college English cannot fully cover all the subject knowledge areas involved in general education, and there is a certain contradiction between the students' college English learning needs and the generalization of college English, while the teacher's knowledge system of interdisciplinary fields is also insufficient [3]. The third view is that college English includes two aspects: English for general education and English for specific purposes. Wang believes that the content of college English teaching should be determined by the university based on the school's orientation, talent training goals, and the level of students [4].

\subsection{Teaching Reform}

Jiang believes that Chinese English general education should pay more attention to literature education that is conducive to improving humanistic care and quality accomplishment, and related textbooks and teaching methods need to be improved [5]. When students read and analyze Western literary works, they can not only promote students' basic language skills, cultivate students' ability to read, appreciate, and understand the original works of English literature, but also enhance students' understanding of Western literature and culture.

Wang pointed out that college English teaching not only needs to pay attention to reading training, but also should focus on cultivating expression skills, so that students' listening, speaking, reading and writing abilities can develop in a coordinated manner, and they need to develop comprehensive application skills in
English, and they need to make full use of modern Educational information technology has changed the original single classroom model that is teacher-centered and teacher-oriented [6].

\subsection{Curriculum System}

Wu and Han proposed a "three sets of vehicles" course content framework, combining language, culture, and multi-disciplinary knowledge, transforming the college English classroom to not only improve the comprehensive ability of using English, but also include cross-cultural communication, a comprehensive and multi-functional classroom that acquires multi-disciplinary knowledge through the use of English [7].

\subsection{Teaching Mode}

Pan believes that Chinese college English general education still has the problem of not integrating general education ideas into college English teaching. The teaching process has a single form, and there is still no innovation in the assessment, evaluation, and feedback mechanisms. The exam model and the goal of improving the passing rate of the "CET-4 and 6" exams, lack of flexibility and general education awareness [8]. Although many students have passed CET-4 and 6, they are unable to communicate fluently in English.

Chen and Deng believe that Chinese college English cultural inheritance function is insufficient, and the inheritance of humanistic spirit needs to be strengthened; the outdated management model makes it difficult to mobilize the subjective initiative and enthusiasm of students; college English still ignores the cultivation of English as a language communication ability [9].

\section{EXISTING PROBLEMS OF GENERAL EDUCATION IN COLLEGE ENGLISH CLASSROOM TEACHING}

Summing up the past experience, general education does play a good guiding role in Universities English classroom reform in China. At the same time, the policy of Universities English teaching has also been changed and the effect is more significant. However, with our indepth understanding of the purpose and significance of general education, we still find many problems in the process of universities' classroom teaching reform.

\subsection{Universities Students Lack English Communicative Competence}

At present, college English has the requirements of reading ability, but it has no communication requirements. Many universities do not offer compulsory courses in oral English and there are few elective courses related to it. They only know how to spell words but 
do not know how to read them and their pronunciation is not standard. In a word, university English teaching still focuses on the accumulation of knowledge. This phenomenon is inconsistent with the goal of general education. Yang argued that the results of many largescale social surveys confirm that the main purpose of Chinese college students' learning is to use English as a communication tool [10]. We learn a language to exchange ideas with different people in the process of communication. We believe this is the best way to broaden our thinking. If we do not use English to communicate, it shows that our understanding of the language only stays in books, and we cannot even understand English dialects. Then the benefits of learning English will be greatly reduced. For example, the papers written by college students may lack richness. Wang argues that universities English teaching should meet the requirements of educational internationalization and cultivate many international talents [11]. The final goal of education is to enable students to have an international vision and the ability to spread Chinese culture abroad. If we can communicate in English, we can not only communicate with others about Chinese culture in English but also learn the essence of foreign culture.

\subsection{Universities English Classroom Teaching Pays Too Much Attention to Students' Test Scores}

At present, university English teaching is used as a test tool and the goal of university English classroom teaching is to enable students to obtain high scores. For example, some schools require college students to pass CET-4 and CET-6. For this purpose, Universities English classroom teaching still pays attention to skill training. Huang had the same view that many English majors have been downgraded to language center which only trains students' listening, speaking, reading, and writing language skills [12]. To pass the exam, students take a lot of examination papers repeatedly. The students feel bored in the process of learning. In this process, students do not realize the interests of language and benefits brought by language. What is more, the teacher's teaching content is mainly the knowledge in books and teachers do not let students understand western culture too much. This leads to high scores, but the knowledge has little effect on students' future development. Wu argued that if students understand the essence of Chinese and Western cultural values, they can make Westerners understand Chinese culture when they can spread Chinese culture in the future [13]. When we learn a language, we should not only focus on scores but also give full play to the learning value of the language, i.e., meeting the needs of society and self-development. Zhuang argued that foreign language is not only a tool but also carries extremely rich humanity [14]. Language should have its characteristics of humanity. Once a language loses that, students will have no meaning when learning the language and meaningless language learning will impede students' selfdevelopment.

\subsection{Universities English Teaching Cannot Meet the Improvement of Students' Professional Ability}

Universities students are divided into different majors to learn professional knowledge when they are freshmen. The most important thing is that college English course content is not closely related to major. Students learn the basic knowledge of English in college classes and they already have strong listening, speaking, reading and writing skills. Learning basic knowledge is not bad for students but we have learned a lot of basic knowledge during the nine-year compulsory education. University is to cultivate talents needed for society and people who has outstanding professional ability and good comprehensive quality required by the society. If we only study the basic knowledge of English (e.g., listening, speaking), students , own professional ability has not been improved and students may lose their competitiveness when they graduate to find a job. Students' learning basic English has little effect on improving their professional ability. $\mathrm{Hu}$ argued that universities English teaching objects are nonforeign language majors who have their own professional learning direction and foreign language is only one of the secondary courses and a tool for them [15]. Students should use this tool to improve their professional level and broaden their knowledge. If students waste their time on basic knowledge, they may lose interest in English because they do not want to repeat learning boring knowledge. What is more, English courses may waste the time learning professional courses.

\section{STRATEGIES FOR IMPROVING GENERAL ENGLISH EDUCATION IN UNIVERSITY}

At present, the viewpoints of college English courses reform include emphasizing "people-oriented" and allround development of students. To achieve a balance between language learning and cultural acquisition, English classes with both instrumental and humanistic features are offered. Although the strategies differ, the overall direction is similar. Among them, the most representative is Wu Dingmin's New Framework of ELT under the Guidance of General Education. He proposes to transform college English course into a comprehensive and multi-functional course for English language learning and skill training, intercultural communication, and acquisition of multi-disciplinary knowledge through English [7]. The main goal of College English general education in China is to cultivate talents with international vision, understanding of Chinese and western culture, cross-cultural communication ability and international communication and cooperation ability. 


\subsection{The Cultivation of communicative competence}

College English general education is different from middle school English teaching in that the single reading and writing training should be weakened, and listening and reading ability should be placed in a more important position. However, college English classes still follow the traditional approach of explaining texts and seldom let students speak. The purpose is to enhance communication and interaction and maximize the communicative role of English. Universities can add oral English training of general Education, such as pronunciation, grammar, vocabulary, and other courses for students to learn communication skills in listening and speaking. Except the oral general elective courses, college English public basic courses should also start to train listening and reading ability by adding oral English learning in the classes. For example, put forward a topic, let students discuss in groups freely, and then invite representatives to state their opinions. Debates and speeches can be held from time to time, requiring everyone to participate in them and open their mouths to communicate. Some universities can invite international students to join in the classes, participating in discussions and communication. Language teaching and skill training should be tied together and complement each other.

\subsection{Combining Language and Cultural Learning}

Language is not only a tool to obtain information and achieve communication purposes, but also has rich humanism. University English learning tends to be too instrumental and focused on a single language goal. Students are supposed to learn more about western culture while learning the language. It should not be just about developing students' listening, speaking, reading, and writing skills, especially after entering the university. Adding cultural background knowledge is a way to increase students' interest in English learning. The teaching method can be bold and innovative, incorporating a variety of topics on world history, science, philosophy, etc. While learning the language, students also increase their knowledge and improve their humanistic quality. Foreign language teaching aims to cultivate students' intercultural communication ability, while cultural communication is two-way. Communication is acquiring the unknown and expressing the known [7]. Therefore, in addition to learning about western culture, we should also add our own culture into college English courses. Students also need to learn and understand how our own culture is expressed in English. Current China has achieved remarkable achievements that are little known and even misunderstood by foreigners. To change this situation, we need our students to learn to use English to introduce our Chinese culture. Adding Chinese culture to college English courses will enable students to have the English ability to explain Chinese culture. When they go to work in the future, they can play a role in promoting China and improving the image of the Chinese people.

\subsection{English and Multidisciplinary Knowledge Learning}

English learning can also be bond with multidisciplinary knowledge learning. The multidisciplinary knowledge here refers to the general knowledge that includes liberal arts, science, and social development. As the person receiving higher education, they are supposed to learn about a full range of nonprofessional knowledge, which could help them improve the insight and be open-minded. At the same time, it can also improve students' interest in English general courses.

In addition, English learning can also be used to help the study of their own majors. Schools can also set up English general courses that have connection with specific profession. Students can memorize and accumulate different vocabulary and read different types of English articles according to the needs of their different majors. For example, medical students could memorize some medical English vocabulary and medical English papers; Law students read international law literature, news, etc. In this way, in the study of English, students will continue to deepen their understanding of the major, so that students can learn professional courses from an international perspective. At the same time, specialized English learning and reading are also conducive to students' future paper writing. It is a significant way to cultivate professional talents with international vision in each field.

\section{CONCLUSION}

This paperhas brought a positive impact on universities' English classroom teaching and solved some problems in teaching. It is an effective way to develop general education in universities English classroom teaching. However, there are still some problems in the process of using general education to solve teaching problems. This paper summed up the three problems and it gives the corresponding strategies by querying some materials and adding our own ideas. One is that college students lack English communicative competence. This is a common phenomenon among college students. This review regards the best solution to this problem is that universities' English classroom teaching should strengthen students' listening and reading ability and enhance oral English learning. The other one is that universities' English classroom teaching pays too much attention to students' test scores. This article advises students to learn the corresponding cultures in the process of language learning and wish teachers to talk about cultural background and join Chinese culture in their 
classes. The last one is that universities' English teaching cannot meet the improvement of students' professional ability. The existence of this problem is very unfavorable to students' future self-development. This research thinks that students' English learning should be combined with multi-disciplinary knowledge. The school can also offer English general courses related to specific majors and let students have an international perspective to broaden their thinking. In the future, this paper may be helpful to educational researchers and teachers. Teachers can improve their teaching methods, curriculum, and interaction with students. Educational researchers can also make educational policies more suitable for students' self-development.

\section{REFERENCES}

[1] Department of Higher Education, Ministry of Education. College English Course Teaching Requirements (Trial) [Z]. Beijing: Higher Education Press, 2004.

[2] Yin H.S., Yan Q.G. Talking about the relationship between college English general education and English teaching for special purposes_-Also on the development direction of the new round of college English teaching reform, [J], Foreign Language Teaching, 2011, 11-16, 11 -16

[3] Chen J.L., Gu S.M. On the status and role of college English courses in general education, $[\mathrm{J}]$, Foreign Language Teaching, 2011, 5-10, 5-10

[4] Wang S.R. Some Thoughts on College English Teaching, [J], Theory and Practice of Foreign Language Teaching, 2011, 3-7, 3-7

[5] Jiang H.X. "General Education" in University and the Cultivation of Compound Talents of English Majors[J]. Journal of Sichuan International Studies University, 2004, 20(6): 144-148. DOI:10.3969/j.issn.1674- 6414.2004.06.028.

[6] Wang S.R. With the starting point of improving the teaching quality of my country's higher education institutions, to promote the reform of college English teaching, [J], Foreign Language Circles, 2006, 4-8+18, 4-8+18

[7] Wu D.M., Han Y.J. Construction of the "Three Cars" Framework for College English from the Perspective of General Education[J]. Foreign Language Audiovisual Teaching, 2010(5): 9-13. DOI:10.3969/j.issn.1001-5795.2010 .05.002.

[8] Pan L. On General Education in the Teaching of "College English"[J]. Jiangsu Higher Education, 2012(4):72-73. DOI:10.3969/j.issn.10038418.2012.04.025.
[9] Chen X. Deng L.J. The Enlightenment of General Education in Ancient Academies to Modern College English Education, [J], Modern University Education, 2018, 23-28, 23-28

[10] Yang H.Z. EAP in China: review, current situation and Prospect. [R]. China EAP research high end forum, Beijing. Beijing Foreign Studies University,2010.

[11] Wang Z, Li J.J. A Study of General Education with English Medium Instruction in Tertiary Education. [J].Computer-Assisted Foriegn Language Education in China,2010, (5).3-8.

[12] Huang Y.S. Calling for a fundamental reform of undergraduate programs for English majors.[J]. Foreign Language World ,2010, (1). 11-16.

[13] Wu. D.M. The concept of "three sets of cars" in College English teaching and the cultivation of highquality talents.[J]. Jiangsu Higher Education , 2005, (4) . 65-67.

[14] Zhuang Z.X. Some reflections on the construction and development of foreign language major in China.[J].Foreign Language World,2010,(1).2-10.

[15] $\mathrm{Hu}$ Z.L. Reflections on China's English education. [J]. Foreign Languages Research, 2002, (3) . 2-5,9.

[16] Chen Y.H. Comprehensive English Curriculum Reform and Construction in the Concept of General Humanistic Education. [J]. Journal of HuBei Correspondence University,2011, 24(2).

[17] Zhou Y. Implement college English general education and cultivate high-quality compound talents[J]. Jiangsu Higher Education, 2008(5):7476. DOI:10.3969/j.issn.1003-8418.2008.05.025.

[18] Chen M.R. A Survey of College English Teaching Literature Research from the Perspective of General Education_-Based on Data Analysis from CNKI Journal Sources [J]. Overseas English (Part 1), 2021(5): 91-93. 